НАУКОВИЙ ВІСНИК

Ventife messenger of L Liv National University of

$-1$

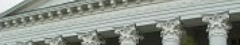

iI 1 is

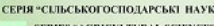

Том 22 № 92
Науковий вісник Дьвівського національного університету ветеринарної медицини та біотехнологій імені С.3. Гжицького. Серія: Сільськогосподарські науки

Scientific Messenger of Lviv National University of Veterinary Medicine and Biotechnologies. Series: Agricultural sciences

UDC 332.1:379.851(477.83)

\title{
Assessment and prospects of development of ecological and tourist potential of Busk district of Lviv region
}

\author{
N. A. Lytvyn, O. P. Rudenko, B. V. Gutyj \\ Stepan Gzhytskyi National University of Veterinary Medicine and Biotechnologies Lviv, Ukraine
}

Article info

Received 12.02.2020 Received in revised form 12.03 .2020

Accepted 13.03.2020

Stepan Gzhytskyi National University of Veterinary Medicine and Biotechnologies Lviv, Pekarska Str., 50, Lviv,

79010, Ukraine.

Tel. + +38-096-813-07-93

E-mail: olgaRudenko86@ukr.net
Lytvyn N. A., Rudenko O. P., \& Gutyj B. V. (2020). Assessment and prospects of development of ecological and tourist potential of Busk district of Lviv region. Scientific Messenger of Lviv National University of Veterinary Medicine and Biotechnologies. Series: Agricultural sciences, 22(92), 81-86. doi: 10.32718/nvlvet-a9214

It is known that today recreation and tourism is one of the most profitable businesses in the world. This sector has recently become increasingly important in the structure of national economies and is developing very rapidly, in countries that give priority to the development of recreation and tourism. This service sector is growing much faster, becoming not only an increasingly important part of national economies, but also the most important filler of the state treasury. In the Lviv region, significant natural and cultural-historical resources in combination with a favorable geographical location have created favorable conditions for the priority of tourism and recreation. In the structure of the natural tourist potential of the region, the Busk district occupies a prominent place, which has a unique geographical location, significant natural resources, rich in historical and cultural monuments. The aim of the research was to show the possibilities of Busk district of Lviv region as a region of ecological and local lore tourism on the basis of the accepted principles of recreational tourism in Ukraine. To achieve this goal, the following tasks were set: to explore the historical-cultural, natural-geographical and tourist-recreational resources of the district; show the state and prospects of development of ecological and tourist resources of Busk district of Lviv region. The results of the analysis of the current state of natural, cultural-historical and recreational-tourist resources of the Busk district of the Lviv region are given, and also the state of the material and technical base of the recreational-tourist sphere in this district is analyzed. In addition, the existing negative tendencies of functioning of this sphere are considered and the ways of the decision of problems of development of recreational and tourist activity in area are allocated. The main directions of development of tourist and recreational potential of Busk district are determined, which should be based on the ideas of natural-historical recreation, observance of ecological standards on environmental cleanliness, preservation of natural-territorial structures and monuments of historical and cultural heritage.

Key words: Lviv region, Busk district, tourism, recreation, tourist and recreational potential, cultural and historical resources, natural and geographical resources, socio-historical resources, protected areas.

\section{Оцінка та перспективи розвитку еколого-туристичного потенціалу Буського району Львівської області}

\author{
Н. А. Литвин, О. П. Руденко, Б. В. Гутий
}

Львівський національний університет ветеринарної медицини та біотехнологій імені С. 3. Гжицького, м. Львів, Україна

Відомо, щзо на сьогодні рекреачія та туризм є одним з найприбутковіших видів бізнесу у світі. Цей сектор останнім часом стає дедалі важливішим у структурі начіональних економік і розвивається дуже швидкими темпами, в краӥнах, шо надають розвитку рекреації та туризму пріоритетного значення. Ця сфера послуг зростає набагато швидше, стаючи не тільки дедалі значушішою частиною начіональних економік, а й найважливішим наповнювачем державної скарбниці. У Львівській області значні природні та культурно-історичні ресурси в поєднанні зі сприятливим географічним розташуванням створили вигідні умови для 
пріоритетності розвитку туризму та рекреаиіі. У структурі природного туристичного потенціалу області чільне місие займає Буський район, який має унікальне географічне розташування, значні природні ресурси, насичений пам'ятками історії та культури. Метою досліджень було на основі прийнятих засад рекреачійного туризму в Украӥні показати можливості Буського району Львівської області як регіону екологічного і краєзнавчого туризму. Для досягнення цієї мети були поставлені такі завдання: дослідити історико-культурні, природно-географічні та туристично-рекреаційні ресурси району; показати стан та перспективи розвитку еколого-туристичних ресурсів Буського району Львівської області. Наведено результати аналізу сучасного стану природних, культурно-історичних $і$ рекреаційно-туристичних ресурсів Буського району Львівської області, а також проаналізовано стан матеріально-технічної бази рекреаційно-туристичної сфери в цььому районі. Також розглянуто існуючі негативні тенденціі функиіонування иієї сфери та виокремлено иляхи вирішення проблем розвитку рекреаційно-туристичної діяльності в районі. Визначено головні напрями розвитку туристично-рекреаційного потенціалу Буського району, щзо мають базуватися на ідеї природноісторичної рекреації, дотриманні екологічних стандартів щуодо чистоти довкілля, збереженні природно-територіальних структур та пам'яток історико-культурної спадщини.

Ключові слова: Львівська область, Буський район, туризм, рекреація, туристично-рекреаційний потенціал, культурноісторичні ресурси, природно-географічні ресурси, суспільно-історичні ресурси, заповідні території.

\section{Вступ}

Найважливішим механізмом управління розвитком туризму, контролю за соціальними, екологічними та економічними наслідками туристичної діяльності є оцінка туристичних ресурсів і територій. Нині у державній і зарубіжній науці накопичений значний досвід оцінки туристичних ресурсів територій та просторового планування рекреаційного господарства на основі такої оцінки. Серед різновидів туризму особливого поширення набуває екологічний туризм (ecological tourism), що переважно здійснюється на рекреаційних територіях національних природних парків, біосферних заповідників, регіональних ландшафтних парків (Kadnichanska, 2008; Horyn, 2018).

Оцінка еколого-туристичного потенціалу і доступних екотуристичних ресурсів природоохоронних територій - одне $з$ найважливіших завдань урбокомпенсаційного природокористування, насамперед для організації екотуристичної діяльності, визначення екотуристичного потенціалу та створення екотуристичного продукту.

Під екотуристичним потенціалом певної природоохоронної території розуміють сукупність всіх екотуристичних ресурсів - природних i антропогенних об'єктів, явищ, властивостей, засобів, можливостей та умов, придатних для формування екотуристичного продукту та здійснення відповідних екологічних турів, екскурсій, програм тощо.

Туризм відіграє важливу роль в економіці, забезпечуючи десяту частину світового валового національного продукту. Дана галузь розвивається швидкими темпами і в найближчі роки може стати найбільш важливою її складовою. В останні роки туризм став одним із найприбутковіших видів бізнесу у світі. Він використовує приблизно $7 \%$ світового капіталу (Herushyns'kyy, 1996).

Однією зі спеціалізацій бізнесу Львівщини традиційно вважається туристична індустрія. Варто також зазначити, що область характеризується високим потенціалом туристичних ресурсів і водночас - невисоким обсягом їх освоєння, наявністю багатого природного потенціалу і одночасно низьким ступенем його використання в туристичних цілях. Різноманітність природних умов i багатство екологорекреаційних ресурсів Львівщини створюють сприятливі умови i для розвитку екологічного туризму (Pavlish, 2013).
У статті розглянуто природно-ресурсні та історико-культурні компоненти туристично-рекреаційного потенціалу Буського району Львівської області, який має унікальне географічне розташування, значні природні ресурси, насичений пам'ятками історії та культури.

Метою досліджень було на основі прийнятих засад рекреаційного туризму в Україні показати можливості Буського району Львівської області як регіону екологічного і краєзнавчого туризму.

Для досягнення цієї мети були поставлені такі завдання:

- дослідити історико-культурні, природногеографічні та туристично-рекреаційні ресурси районy;

- показати стан та перспективи розвитку екологотуристичних ресурсів Буського району Львівської області.

\section{Результати та їх обговорення}

Буський район є одним із районів, що розташований у східній частині Львівської області, в пониззі річки Західного Бугу, який відкриває туристам шлях зі сходу до Львова. Він межує з Бродівським, Радехівським, Кам'янка-Бузьким, Золочівським та Пустомитівським районами області (площа 850 кв. км). У складі району місто Буськ - адміністративний центр та селища міського типу Красне і Олесько (Pasport Lvivskoi oblasti).

Через територію Буського району проходить міжнародна залізнична магістраль до столиць багатьох європейських держав (вузлова станція Красне). Автотраса Київ - Чоп проходить біля перлини області Олеського замку (14-17 ст.), який користується популярністю серед туристів і входить до найвідомішого туристичного маршруту “Золота підкова Львівщини” (об'єднує Олеський, Золочівський, Підгорецький та Свірзький замки).

Завдяки своєму вигідному географічному розташуванню на перетині туристичних шляхів, наявності 19 пам'яток архітектури національного значення та 57 місцевого район має значний потенціал для розвитку туризму.

Історико-культурні ресурси включають пам'ятки архітектури, історії, археології та інше. Всього в районі взято під охорону 76 пам'яток архітектури, 19 з яких мають статус “національного значення”. Серед 
них: церква Св. Параскеви (1708р.) та церква св. Онуфрія (1680 р.) в м. Буську, монастир капуцинів 3 келіями 1739 р. (селище Олесько), церкви Св. Михаїла 1697 p. та Собору Пресвятої Богородиці 1750 p. (с. Кути), церква Вознесіння 1680 р. (с. ВолицяДеревлянська).

Крім того, в районі налічується 57 пам'яток місцевого значення: палац графа Бадені (XIX століття), костел Святого Станіслава (1780), синагога (XVIII), найдавніший в центральній і Східній Свропі єврейський цвинтар, ансамбль пам'ятки архітектури початку XX століття - церква Св. Миколая за проєктом одного 3 найвидатніших зодчих церковного будівництва Свгена Нагірного, ансамбль житлових будинків на площі Ринок та багато інших.

Замки Львівщини є основними туристичними принадами довкола Львова. Їхня велична архітектура, містична історія і мальовничі пейзажі завжди приваблювали людей. Для популяризації замкової спадщини Галичини з ініціативи Бориса Возницького в Буському районі був створений маршрут, який пролягає через селище Олесько, “Золота підкова Львівщини”. Він зручний тим, що замки розташовані поблизу трас і туристи протягом дня встигають детально оглянути ïx ycix (Hovor, 2015). Музей-заповідник “Олеський замок” - відділ Львівської галереї мистецтв, історикокультурна пам'ятка XIV-XVII ст., у фондосховищі якого зібрано 12127 експонатів (Turystychno reakreatsiinyi potentsial, 2017).

Олеський замок, можливо, найвідоміший замок Львівщини, відроджений $з$ цілковитої руїни. Понад шість століть стоїть він на високому пагорбі та $є$ свідком і учасником багатьох подій, що навічно увійшли в історію (Hovor, 2015).

На території м. Буська - три городища VI-VII ст. Починаючи з 1983 року літописний Бужськ, сучасний Буськ - одне з найдавніших міст України - досліджували декілька археологічних експедицій. 32000 р. інститут археології Львівського національного університету ім. Івана Франка проводив розкопки на вул. Воляни та поблизу Буської гімназії ім. Петрушевича. Археологічні розкопки дали цікавий речовий матеріал - фрагменти керамічного посуду X-XII ст., вироби із заліза, скла, ювелірні прикраси, предмети озброєння (Alieshuhina et al., 2015).

На території Буського району розміщено 12 громадських музеїв, один з них - музей о. Маркіяна Шашкевича в с. Новосілки, який має звання "Народний”. Його вже відвідали тисячі туристів з України та представники діаспори, у ньому збережено і виставлено в експозиціях надзвичайно цікаві й оригінальні історичні пам'ятки. Також великою популярністю серед туристів користується історико-краєзнавчий музей м. Буська, частина експонатів якого присвячена життю і діяльності видатних вихідців 3 м. Буська та Буського району - співачки Іванки Мигаль, художниці Софії Караффи-Корбут, родини Свєнціцьких та ін. Також в експозиції музею - знаряддя праці, предмети побуту, вишивка та ін. Не менш цікавим для туристів $\epsilon$ приватний музей родини Грушицьких "Народна скарбничка", який відтворює побут української родини кін. XIX - поч. XX ст. (Kutsenko, 2009).
Найважливішим завданням туристичної галузі $є$ проведення цікавих екскурсійних заходів. Для залучення туристів та забезпечення змістовного відпочинку розробляють маршрути подорожей, які можуть бути різними, залежно від того, де хоче побувати і що хоче побачити турист (Svyda \& Mykyta, 2013).

У Буському районі Львівської області, завдяки його унікальним природо-рекреаційним ресурсам, історико-архітектурній спадщині є різноманітні тематичні подорожі. Нині в районі діють чимало туристичних маршрутів різної складності, які забезпечують розвиток внутрішнього туризму, а саме: пішохідні, автобусні, тощо. Найвідомішими туристичними маршрутами Буського району є:

\section{Туристичний маршрут Галицька Венеція}

На цьому маршруті туристи мають змогу милуватися мальовничими пейзажами Західного Бугу, прекрасними пам'ятками історії, культури та природи Надбужанщини. Даний маршрут включає відвідування села Новосілки, в якому останні роки свого життя провів “Будитель Галичини” о. Маркіян Шашкевич і 3 нагоди цього тут відкрито музей; села Новий Милятин, в якому збережені дві цікаві пам'ятки: костел Воздвиження Чесного Хреста (1740р.) та корчмазаїзд (XVIII ст.). У костелі колись зберігалася чудодійна ікона Iсуса з Милятина, вважалося, що якщо навколішки обповзти храм тричі та вклонитися чудотворній іконі, то можна було позбутися невиліковних хвороб; села Ракобовти, яке щорічно відвідують тисячі туристів, адже тут похований стигматик Степан Навроцький, в якого з рук, чола, ніг та ран біля серця текла кров, також він передбачив багато подій з новітньої історії України. 3 часу поховання Степана Навроцького і дотепер село Ракобовти оминають лиха і катаклізми, а багато людей оздоровлюють біля його могили душу і тіло; села Волиця-Деревлянська, в мальовничій місцевості якого, на пагорбі над річкою, розташована церква Вознесіння Господнього (1680р.) 3 чудовим семиярусним іконостасом роботи видатного художника Івана Рутковича, що належить до найкращих шедеврів галицької архітектурної школи. Нащадки древніх бужан, якими керував слов'янський князь Бож, дуже гордяться тим, що тут встановлений перший в країні монумент з нагоди незалежності України. Буськ славиться своїми архітектурними пам'ятками: палац графа Бадені з парком (XVIII ст.), зразком галицької народної архітектури - дерев'яною церквою святого Онуфрія (1680 р.), дерев'яною церквою святої Параскеви (1708 р.) з живописом Леонтовича й Сірського та костелом святого Станіслава (1795 р.); села Куткір, в якому народилася художниця Софія Караффа-Корбут. У центрі села доживають останні дні руїни величного в минулому костела, в якому колись зберігалася чудотворна ікона Марії Сніжної.

\section{Туристичний маршрут Скарби Бузеччини}

На цьому маршруті туристи мають змогу відвідати Площу Ринок, яка завжди була центром громадського життя. У цьому мальовничому серці міста досі збереглись ошатні дво-триповерхові будиночки. Осяяна ранковим сонцем, вона зачаровує туристів своєю неповторною архітектурою; Буську Ратушу; Палац 
графа Бадені, збудований в 1810 р. Войцехом Міром. Це - двоярусна будівля з головним корпусом та бічними крилами. Прикраса палацу - двоярусний портик iз іонічними колонами та балконом з балюстрадою; Церкву Св. Параскеви, яка збудована у 1708 р. в традиційному народному стилі на мальовничому пагорбі. Своєю структурою церква нагадує ротонду з чудовим народним вівтарем і притвором; Церкву Св. Онуфрія, яка розташована в мальовничому місці на Волянах, збудована в 1680 р. При церкві туристи можуть оглянути оригінальну каплицю, яку споруджено в дуплі тисячолітнього дуба, котрий в обхваті мав 6 метрів; Костел Св. Станіслава; Церкву Св. Миколая, збудовану за проєктом Свгена Нагірного; Синагогу, збудовану в XVIII ст.; село Кути, де туристи мають змогу відвідати Церкву Св. Михаїла, яка побудована у 1697 році майстром Григором Гебичим та Церкву Собору Пресвятої Богородиці, яка розташована в південній околиці села; селище Олесько, де туристам проводять екскурсію по Олеському замку, також вони мають змогу побувати в Комплексі монастиря капуцинів 1739 р. пам'ятці архітектури пізнього бароко i рококо та в Костелі св. Трійці XVI ст., заснованому 1481 року Петром Сененським. Наступним місцем, яке можуть відвідати туристи, $\epsilon$ село ВолицяДеревлянська, в якому туристи мають змогу відвідати Церкву Вознесіння Господнього, що розташована в мальовничій місцевості на околиці села, на невисокому пагорбі над річкою Західний Буг. А у селі Новий Милятин - корчму XVIII ст. На території села, крім багатьох пам'яток культурної спадщини, розташоване й унікальне сірководневе озеро. 3 глибокої свердловини фонтаном на декілька метрів б’є вода зеленкуватого кольору з запахом сірки (сірководню), де місцеві жителі та туристи залюбки проводять свій вільний час біля джерела. У селищі Красне туристи мають змогу оглянути Церкву Св. Пророка Іллі в бойківському стилі, яка є найстарішою пам'яткою селища, що збудована в 1750 році з соснових брусів і розташована в центрі селища на правому березі ріки Гологірки.

Львівщина - це великий природний заповідник, зокрема і в Буському районі є низка природоохоронних територій (Rudenko, 1999; Haiduk, 2000).

Алея вікових лип (площа 2 га) - ботанічна пам'ятка природи місцевого значення в Україні, що розташована в межах Буського району Львівської області, на захід від села Куткір. Дерева на Алеї вікових лип висаджені в 1877 році місцевою графинею Лончинською (Aleia vikovykh lyp).

Бу́ський парк (Парк імені Івана Франка) (площа 8 га) - парк-пам'ятка садово-паркового мистецтва загальнодержавного значення в Україні, який розташований у центральній частині міста Буська Львівської області. Статус парку-пам'ятки садово-паркового мистецтва надано з метою збереження старовинного парку, закладеного в XVII ст, у якому зростає багато вікових дерев. Через парк тече річка Західний Буг, до якої при західній частині парку впадає річка Полтва. Поруч зі східною частиною парку розташований Палац Бадені (Buskyi park imeni Ivana Franka).

Га́ївський зака́зник (площа 50,6 га) - лісовий заказник місцевого значення в Україні, що розташова- ний у межах Буського району Львівської області, біля сіл Гаївське і Заводське. Створений з метою збереження лісового масиву, в якому зростають червонокнижні види рослин, що є типовими для Малого Полісся (Halsillis).

Журавли́ний (площа 167,2 га) - ландшафтний заказник місцевого значення в Україні, який розташований у межах Буського району Львівської області, на території Соколянського лісництва. Статус надано для збереження одного з основних на Львівщині місць гніздування журавля сірого, виду, занесеного до Червоної книги України (Stvoreno landshaftnyi zakaznyk mistsevoho znachennia "Zhuravlynyi”, 2016).

Північне Поді́лля - природоохоронна територія, національний природний парк у східній частині Львівської області. Парк охоплює південну частину Бродівського району, центральну, частину західної, східну та північно-східну частину Золочівського району та східну частину Буського району. Територія належить до фізико-географічних районів Гологір та Вороняків, що разом із Розточчям та Кременецькими горами (Тернопільська область) формують північнозахідний край Подільської височини. На цій території сформувалися унікальні осередки рослинних видів, а також букові лісостани, що ростуть на північносхідній межі ареалу та становлять особливу цінність у загальноєвропейському масштабі. Тут бере початок річка Західний Буг, що має міждержавне значення. На території парку поширено понад 200 видів рослин різного статусу охорони.

Крім природничої цінності, територія проектованого парку відзначається значною історикокультурною спадщиною, це об’єкти так званого “Золотого кільця" замків Львівщини, численні храми та інші пам'ятки культури. Важливе значення НПП має для охорони верхів їв басейну р. Західного Бугу, а також для функціонування ПівнічноподільськоОпільського макроекокоридору регіональної екомережі.

НПП "Північне Поділля" володіє значним рекреаційно-туристичним потенціалом для розвитку еколого-пізнавального, історико-культурного, сакрального туризму, а також спортивного (кінного, велосипедного, пішого) туризму. В навколишніх населених пунктах - сприятливі умови для розвитку агротуризму. Проте туризм у парку ще недостатньо розвинутий. Не всі існуючі рекреаційно-туристичні ресурси в повній мірі залучаються для розвитку туристичної діяльності (Naukove obgruntuvannia stvorennia Natsionalnoho pryrodnoho parku "Pivnichne Podillia").

Соко́ля (площа 53,9 га) - заповідне урочище місцевого значення в Україні, що розташоване в межах Буського району Львівської області, неподалік від села Соколя. Перебуває у віданні ДП “Буський лісгосп” (Соколянське лісництво, кв. 45) під охороною лісові ландшафти в долині річки Західний Буг. Тут зростають цінні високопродуктивні дубово-соснові насадження природного походження, а також це місце облюбували бобри (Zapovidne urochyshche "Sokolia").

Сосно́вий ліс (площа 11 га. ) - заповідне урочище місцевого значення в Україні, яке розташоване в межах Буського району Львівської області, на північний 
захід від села Ожидів. Створене з метою збереження частини лісового масиву з цінними високопродуктивними насадженнями сосни звичайної та лісового цілісного ландшафту в межах Малого Полісся (Zapovidne urochyshche "Sosnovyi lis").

Сторонибаби́ (площа 30 га) - заповідне урочище місцевого значення в Україні, що розташоване в межах Буського району Львівської області, на північний схід від села Сторонибаби. Створено з метою збереження лісового масиву 3 цінними високопродуктивними насадженнями дуба звичайного природного походження (Storonybaby).

Зважаючи на зручне географічне розташування (близькість приміської та прикордонної зони), розвиток екскурсійно-туристичного бізнесу, Буський район має непогані передумови для досягнення високого рівня розвитку інфраструктури в регіоні. Водночас подальший розвиток туристично-рекреаційної галузі у Буському районі гальмується через:

- невиразний образ Бузеччини на туристичному ринку;

- низький рівень розвитку туристичнорекреаційної інфраструктури;

- незадовільний стан доріг;

- нерозвіданість рекреаційних ресурсів;

- недостатній рівень благоустрою водойм для туристичних потреб;

- погане пристосування для потреб спеціалізованого туризму (лижний, велосипедний, кінний);

- відсутність дорожніх вказівників і туристичноінформаційних знаків;

- незадовільний стан пам'яток історикоархітектурної спадщини, що не підлягають використанню для туристичних потреб;

- недостатність методичної, організаційної, інформаційної та матеріальної підтримки з боку держави;

- низьку якість та недостатній асортимент туристичних послуг;

- недостатність туристичної інформації як для туристів, так і для підприємств, що надають послуги у сфері туризму (карт, рекламної продукції інформації про район);

- неефективну діяльність відповідних структур щодо забезпечення екологічної безпеки територій для розвитку рекреаційного бізнесу;

- низьку історичну та екологічну свідомість мешканців (Novytska, 2013; Nikolaiev, 2016).

\section{Висновки}

Отже, підсумовуючи наведене, можна зробити такі висновки:

1. Буський район має всі передумови, щоб стати одним з передових рекреаційно-туристичних районів Львівської області, однак аналіз сучасного стану функціонування сучасної рекреаційної сфери свідчить про те, що ефективність іiі діяльності стримується через невирішеність низки вищенаведених проблем.

2. Основними напрямами формування ефективного механізму реалізації стратегічних завдань подаль- шого розвитку рекреаційно-туристичної сфери мають бути:

- проведення екологічного моніторингу ресурсів району;

- створення належних умов для безпечного відпочинку туристів у зонах відпочинку;

- створення нових і удосконалення існуючих туристичних маршрутів;

- підвищення кваліфікації осіб, які працюють у сфері туризму та якості й обсягу пропонованих послуг туристичних об'єктів;

- проведення регулярних навчань (семінаритренінги), стажування для осіб, які планують займатися чи вже займаються агротуризмом та здійснювати їх сертифікацію;

- поліпшення стану навколишнього середовища району, забезпечення його екологічної стабільності та привабливості ландшафтів;

- необхідною також є належна правова база, яка б дозволяла законно отримувати гроші від рекреаційної діяльності та була б ефективною при подоланні та відверненні правопорушень в екологічній сфері. Важливим $є$ збільшення площі об'єктів природнозаповідного фонду України, розробка заходів щодо збереження зональних ландшафтів та екосистем.

Вирішення проблем та врахування перспектив розвитку еколого-туристичного потенціалу Буського району стане запорукою модернізації наявного рекреаційного та туристичного потенціалу району, динамічного розвитку рекреаційно-туристичної сфери, забезпечення іiї сталої конкурентної спроможності серед інших областей.

\section{References}

Aleia vikovykh lyp (Buskyi raion) Rezhym dostupu: https:/uk.wikipedia.org/wiki/Алея_вікових_лип_(Бу ський_район) (in Ukrainian).

Alieshuhina, N. O., Baranovska, O. V., Baranovskyi, M. O., Zelenska, O. O., Smal, I. V., \& Filonenko, I. M. (2015). Rekreatsiino-turystychni resursy Ukrainy z osnovamy turystychnoho resursoznavstva. Navchalnyi posibnyk. Chernihiv: Vydavnytstvo ChNTU (in Ukrainian).

Buskyi park imeni Ivana Franka. Rezhym dostupu: https://zruchno.travel/ObjectEntity/ObjectEntity?lang= ua\&idCrm=5d3af283-fa3e-21d3-bc7c-58dbc2c11672 (in Ukrainian).

Haiduk, A. (2000). Otsinka turystychnykh resursiv Lvivskoi oblasti ta yii praktychne zastosuvannia. Sotsialno-ekonomichni doslidzhennia v perekhidnyi period. Stalyi rozvytok ta ekolohichna bezpeka (rehionalna polityka). Shchorichnykh naukovykh prats, 20, 200-212 (in Ukrainian).

"Halsillis" aktyvno rozvyvavaie pryrodno-zapovidnu merezhu. Rezhym dostupu: http://galsillis.org.ua/novyny/ galsillis-aktyvno-rozvyvavaye-pryrodno-zapovidnumereju (in Ukrainian).

Herushyns'kyy, Z. Y. (1996). Typolohiya lisiv Ukrayins'kykh Karpat: Navch. posib. L'viv: Piramida (in Ukrainian). 
Horyn, I. (2018). Pryrodni turystychno-rekreatsiini resursy Lvivshchyny: struktura, otsinka potentsialu ta kharakteru suchasnoho vykorystannia Rekreatsiina heohrafiia i turyzm. Naukovi zapysky, 2, 138-147 (in Ukrainian).

Hovor, H. (2015). "Zolota pidkova Lvivshchyny”: rushaiemo na eskursiiu po zamkakh Lvivskoi oblasti Rezhym dostupu: https://lviv.vgorode.ua/news/ dosuh_y_eda/258044-zolota-pidkova-lvivschynyzamky-lvivskoi-oblasti (in Ukrainian).

Kadnichanska, M. (2008). Osoblyvosti rozvytku ekoturyzmu u natsionalnykh pryrodnykh parkakh Lvivshchyny. Visnyk Lvivskoho universytetu. Seriia mizhnarodni vidnosyny, 24, 101-105. https://tourlib.net/statti_ukr/kadnichanska.htm (in Ukrainian).

Kontseptsiia rozvytku sanatorno-kurortnoi sfery, turyzmu i vidpochynku u Lvivskii oblasti (2002). Lviv (in Ukrainian).

Kutsenko, V. (2009). Stratehiia formuvannia vysokotekhnolohichnoho turystskoho kompleksu Ukrainy. Kraieznavstvo. Heohrafiia. Turyzm, 12(593), 6-7 (in Ukrainian).

Naukove obgruntuvannia stvorennia Natsionalnoho pryrodnoho parku "Pivnichne Podillia" (2009). Derzhavne upravlinnia ekolohii ta pryrodnykh resursiv u Lvivskii oblasti. Lviv (in Ukrainian).

Nikolaiev, K. D. (2016). Ekolohizatsiia ta rozvuytokm silskoho zelenoho turyzmu v Ukraini: monohrafiia. K. (in Ukrainian).

Novytska, S. (2013). Ekolohichnyi turyzm yak priorytetnyi napriamok staloho rozvytku turystychnoi sfery. Naukovi zapysky TNPU imeni V. Hnatiuka, 2, 390 394. http://nbuv.gov.ua/UJRN/NZTNPUg_2013_2_24 (in Ukrainian).

Pasport Lvivskoi oblasti / Lvivska oblasna rada Rezhym dostupu: https://archive.lvivoblrada.gov.ua/паспорт львівської_області_394cms.htm (in Ukrainian).
Pavlish, L. V. (2013). Lvivshchyna yak perspektyvnyi rehion Ukrainy dlia rozvytku turyzmu ta rekreatsii. Torhivlia, komertsiia, pidpryiemnytstvo, 15, 124-128 http://nbuv.gov.ua/UJRN/Torg_2013_15_30 (in Ukrainian).

Rudenko, V. P. (1999). Heohrafiia pryrodno-resursnoho potentsialu Ukrainy. U 3-kh chastynakh: Pidruchnyk. K.: VD “K. M. Akademiia". Chernivtsi: Zelena Bukovyna (in Ukrainian).

Storonybaby. Rezhym dostupu: https://www.wikiwand.com/ uk/Сторонибаби (in Ukrainian).

Stvoreno landshaftnyi zakaznyk mistsevoho znachennia "Zhuravlynyi" (2016). Departament ekolohii ta pryrodnykh resursiv. Rezhym dostupu: https://deplv.gov.ua/2016/10/25/stvoreno-landshaftnyj -zakaznyk-misczevogo-znachennya-zhuravlynyj (in Ukrainian).

Svyda, I. V., \& Mykyta, M.-N. M. (2013). Realizatsiia idei formuvannia turystychnykh marshrutiv Karpatskoho rehionu. Naukovyi visnyk Uzhhorodskoho universytetu: seriia: Ekonomika, 1(38), 254-257. Rezhym dostupu: https://dspace.uzhnu.edu.ua/jspui/ handle/lib/14683 (in Ukrainian).

Turystychno reakreatsiinyi potentsial (2017). Buska raionna derzhavna administratsiia Lvivskoi oblasti. Rezhym dostupu: https://busk-rda.gov.ua/туристична -привабливість/туристично-реакреаційнийпотенціал-та-памятки-культ-спадщини-району (in Ukrainian).

Zapovidne urochyshche "Sokolia". Rezhym dostupu: https://lvivlis.gov.ua/zapovidni_urochysha?id=91 (in Ukrainian).

Zapovidne urochyshche "Sosnovyi lis". Rezhym dostupu: https://lvivlis.gov.ua/zapovidni_urochysha?id=94 (in Ukrainian). 